\title{
Lipoprotein Lipase Activity in Marasmic Type of Protein-Calorie Malnutrition*
}

\author{
CIHAD T. GÜRSON and GÜNAY SANER \\ with the technical assistance of Serap Soyak \\ From the Department of Paediatrics, University of Istanbul, Cerrahpașa, Istanbul, Turkey
}

Kwashiorkor and marasmus constitute the two major syndromes of protein-calorie malnutrition encountered in infants and young children in many parts of the world.

The clinical and metabolic characteristics of these syndromes differ significantly from one another, one difference being the fat metabolism. The increase of free fatty acids (FFA) in plasma has been accepted as the key factor causing fatty liver in kwashiorkor (Korn, 1955; Feigelson et al., 1961; Lewis et al., 1964; Fletcher, 1966; Bar-on and Stein, 1968). The role of lipoprotein lipase (LPL) in the mobilization of FFA is well known.

In this paper, plasma FFA and LPL levels, as well as the effect of heparin on the activation of this enzyme and its kinetics in plasma in various stages of marasmus will be presented.

\section{Material and Methods}

Fourteen cases of marasmus have been included in the study. The mean age of the series was 14.3 months (range 8 to 25 months). The mean weight loss (as a percentage of normal weight for age) was $48.0 \%$ (range $29 \cdot 4 \%$ to $57 \cdot 9 \%$ ). Retardation in height (as a percentage of normal height for age) was $12 \cdot 4 \%$ (range $2 \cdot 3 \%$ to $21 \cdot 5 \%$ ). On clinical examination, hepatomegaly was not present in any of the cases. There were no other noteworthy clinical findings.

The first group of tests was carried out within 11 days of admission to the hospital, the second group of tests 6 weeks later, and the final group of tests 8 weeks after the second one.

Five normal controls were selected. Instead of the marasmic infants' age-group, children of 8 months to 12 years old were chosen to facilitate the study technically. It has already been established that the postheparin LPL activity found in the newborn and in children up to 17 years of age showed no appreciable difference (Högstedt and Lindquist, 1963).

Received May 16, 1969.

$\star$ This paper was presented in part at the VIIIth 'International Congress of Nutrition' in Prague.
Heparin tests. After a fasting period of 12 hours, $12 \mathrm{U} / \mathrm{kg}$. of heparin was administered intravenously. Blood was collected before and at the 15th, 45th, 60th, and 90th minutes after the administration of heparin. Plasma LPL activity, FFA, and glucose levels were determined within one hour of the collection.

FFA in plasma were determined according to Dole's method as modified by Burns (Dole and Meinertz, 1960; Burns et al., 1963). Kern's method was used in the determination of LPL activity, details of which were given previously (Kern, Steinmann, and Sanders, 1961; Gürson and Etili, 1968). LPL activity was expressed as the amount of FFA in $\mu \mathrm{Eq} / \mathrm{ml}$. per $60 \mathrm{~min}$. produced from the substrate.

A glucose oxidase method was used to determine blood glucose (Marks, 1959).

Pilocarpine iontophoresis was carried out on all cases in this series.

The statistical validity of the results was investigated by using the Student test. Half-life, zero time, extrapolated activity, and $\mathrm{K}$ slope constants were calculated in accordance with Boberg and Carlson's formulae (Boberg and Carlson, 1964).

\section{Results}

The mean LFI activity in normal controls was found to be $0 \cdot 298 \pm 0 \cdot 167 \mu \mathrm{Eq} / \mathrm{ml}$. per $60 \mathrm{~min}$. The mean values after heparin at $15,45,60$, and 90 minutes were $4 \cdot 013 \pm 0.894,1 \cdot 289 \pm 0.491$, $0.544 \pm 0.343$, and $0.399 \pm 0.319 \mu \mathrm{Eq} / \mathrm{ml}$. per 60 min., respectively.

In cases of marasmus, the results of the first tests were as follows: the mean initial value was $0 \cdot 404 \pm 0.299 \mu \mathrm{Eq} / \mathrm{ml}$. per $60 \mathrm{~min}$. The values after heparin were $2 \cdot 125 \pm 0.916,0.678 \pm 0.432$, $0.469 \pm 0.263$, and $0.325 \pm 0.247 \mu \mathrm{Eq} / \mathrm{ml}$. per $60 \mathrm{~min}$. at the $15 \mathrm{th}, 45 \mathrm{th}, 60 \mathrm{th}$, and 90 th minutes.

When the tests were repeated on 9 of the cases 6 weeks later, the mean initial value for LPL activity was found to be $0 \cdot 294 \pm 0 \cdot 128 \mu \mathrm{Eq} / \mathrm{ml}$. per $60 \mathrm{~min}$. and the values after heparin at the same time intervals as above were $2 \cdot 221 \pm 0.964$, $0 \cdot 874 \pm 0.470,0.473 \pm 0 \cdot 208$, and $0 \cdot 270 \pm 0 \cdot 129$ $\mu \mathrm{Eq} / \mathrm{ml}$. per $60 \mathrm{~min}$., respectively. 
In four of the cases, the heparin test was repeated 14 weeks after admission. The initial LPL activity at this time was found to be $0 \cdot 354 \pm 0 \cdot 160$ $\mu \mathrm{Eq} / \mathrm{ml}$. per $60 \mathrm{~min}$.; and the values after heparin $3 \cdot 670 \pm 1 \cdot 405,1 \cdot 790 \pm 1 \cdot 374,1 \cdot 079 \pm 0 \cdot 564$, and $0.777 \pm 0.475 \mu \mathrm{Eq} / \mathrm{ml}$. per $60 \mathrm{~min}$. (Fig.).

An analysis of the results showed that no significant differences existed between plasma LPL activity before heparin in normal controls and in cases of marasmus in severe as well as recovery stages. On the other hand, the LPL activities after heparin at 15 minutes in the severe stage of marasmus were significantly lower than in normal controls $(p<0 \cdot 01)$.

Table I shows the mean half-life for LPL activity, the mean zero time, the mean LPL activity extrapolated to zero time, and the mean $\mathrm{K}$ slope constant in normal controls as well as in different stages of marasmus.

Table II presents the initial mean plasma FFA level in normal controls and the values after heparin in the case of marasmus.

The results of pilocarpine iontophoresis showed the sodium values to be $23.2 \pm 13.9 \mathrm{mEq} / 1$; those for chloride were $23 \cdot 7 \pm 15 \cdot 5 \mathrm{mEq} / \mathrm{l}$., and those for potassium $14 \cdot 1 \pm 3 \cdot 9 \mathrm{mEq} / \mathrm{l}$.

\section{Comments}

In order to clarify the causes of fatty liver in kwashiorkor, a study of material taken from biopsies and necropsies enables us to make certain hypotheses in connexion with the origin of fat accumulation in the liver.

From an analysis of the composition of fat found in the liver and in other fat tissues in the body, it was apparent that the lipid accumulating



FIG.-Plasma lipoprotein lipase activity in marasmic cases and in normal controls after heparin administration at different times and stages (PCM: Protein-calorie malnutrition).

TABLE I

Kinetics of LPL Activity in Plasma of Marasmic Cases after Single Dose of Heparin at Different Stages of Disease

\begin{tabular}{|c|c|c|c|c|c|c|c|}
\hline & & & & $\begin{array}{l}\text { Elimination Rate of } \\
\text { Lipoprotein Lipase } \\
\text { t } \frac{1}{2} \text { (min.) }^{\text {min. }}\end{array}$ & $\begin{array}{c}\text { Zero Time } \\
(\mu \mathrm{Eq} / \mathrm{ml} . / \text { per } 60 \mathrm{~min} .)\end{array}$ & $\begin{array}{l}\text { K slope constant } \\
(\% \text { min. })\end{array}$ & $\begin{array}{l}\text { LPL Activity Extra- } \\
\text { polated to Zero Time } \\
(\mu \text { Eq/ml. per min.) }\end{array}$ \\
\hline $\begin{array}{l}\text { Controls (5) } \\
\text { Marasmic cases } \\
\text { Upon admission (14) } \\
6 \text { weeks later (9) } \\
14 \text { weeks later (4) }\end{array}$ & $\begin{array}{l}\cdots \\
\cdots \\
\cdots \\
\cdots\end{array}$ & $\begin{array}{l}\cdots \\
\cdots \\
\cdots \\
\cdots\end{array}$ & $\begin{array}{l}\cdots \\
\cdots \\
\cdots\end{array}$ & $\begin{array}{c}24 \pm 2 \\
28 \cdot 2 \pm 5 \cdot 9 \\
28 \cdot 2 \pm 4 \cdot 4 \\
26 \cdot 5 \pm 4 \cdot 2\end{array}$ & $\begin{array}{l}6 \cdot 10 \pm 1 \cdot 3 \\
3 \cdot 2 \pm 1 \cdot 4 \\
3 \cdot 3 \pm 1 \cdot 7 \\
5 \cdot 3 \pm 1 \cdot 8\end{array}$ & $\begin{array}{l}2 \cdot 90 \pm 0 \cdot 25 \\
2 \cdot 54 \pm 0 \cdot 48 \\
2 \cdot 50 \pm 0 \cdot 36 \\
2 \cdot 66 \pm 0 \cdot 43\end{array}$ & $\begin{array}{l}0.0712 \pm 0.0094 \\
0.0397 \pm 0.0180 \\
0.0403 \pm 0.0198 \\
0.0589 \pm 0.0067\end{array}$ \\
\hline
\end{tabular}

^ Figures in parentheses represent the number of cases.

\begin{tabular}{l|c|c}
\hline & $\begin{array}{c}\text { Controls vs. Marasmus } \\
\text { (upon admission) }\end{array}$ & $\begin{array}{c}\text { Marasmus (upon ad- } \\
\text { mission) vs. 14 weeks } \\
\text { later }\end{array}$ \\
\hline $\begin{array}{l}\text { Half-life time } \\
\begin{array}{l}\text { Kero time } \\
\text { Extope constant }\end{array}\end{array}$ & $\begin{array}{c}\text { Not significant } \\
\mathrm{p}<0.01 \\
\text { Not significant } \\
\mathrm{p}<\mathbf{0} \cdot 01\end{array}$ & $\begin{array}{c}\text { Not significant } \\
\mathrm{p}<0.05 \\
\text { Not significant } \\
\text { Not significant }\end{array}$ \\
\hline
\end{tabular}


TABLE II

Free Fatty Acids (mEq/l.) in Plasma of Marasmic Cases after Heparin Administration at Different Times and Stages

\begin{tabular}{|c|c|c|c|c|c|c|}
\hline & & Initial & $15 \mathrm{~min}$. & $45 \mathrm{~min}$ & $60 \mathrm{~min}$. & $90 \mathrm{~min}$. \\
\hline $\begin{array}{l}\text { Controls }(5)^{\star} \ldots \\
\text { Upon admission (14) } \\
6 \text { weeks later }(9) \\
14 \text { weeks later }(4)\end{array}$ & $\begin{array}{l}\cdots \\
\cdots \\
\cdots\end{array}$ & $\begin{array}{l}0.450 \pm 0 \cdot 199 \\
0.493 \pm 0.226 \\
0.418 \pm 0 \cdot 122 \\
0.538 \pm 0.119\end{array}$ & $\begin{array}{l}0.650 \pm 0.229 \\
0.663 \pm 0.315 \\
0.574 \pm 0.165 \\
0.577 \pm 0.075\end{array}$ & $\begin{array}{l}0.585 \pm 0.256 \\
0.615 \pm 0.272 \\
0.520 \pm 0.175 \\
0.527 \pm 0.033\end{array}$ & $\begin{array}{l}0.485 \pm 0.283 \\
0.569 \pm 0.236 \\
0.532 \pm 0.135 \\
0.516 \pm 0.104\end{array}$ & $\begin{array}{l}0.505 \pm 0.250 \\
0.595 \pm 0.305 \\
0.528 \pm 0.143 \\
0.462 \pm 0.065\end{array}$ \\
\hline
\end{tabular}

* Figures in parentheses represent the number of cases.

No significant differences existed in the FFA values between normal controls and cases of marasmus in the various stages.

in the liver was not derived from the adipose tissue. The fatty acid composition of the fat suggests that it might be synthesized in the liver from dietary carbohydrates (MacDonald, Hansen, and Bronte-Stewart, 1963; Fletcher, 1966). Contrary to this theory, it has been postulated that adipose tissue may be the chief source of the lipid accumulating in the liver during the late stage of kwashiorkor, being transported to that organ in the form of FFA (Lewis et al., 1964). Levels of FFA in plasma were found to be high in kwashiorkor. Hadden and Rutishauser (1967) showed that FFA in plasma in marasmus, where a grossly fatty liver is not characteristic, were not increased as in kwashiorkor. The present study supports these findings.

As is known, the LPL enzyme brings about the hydrolysis of triglyceride, which produces the FFA. Animal experiments and observations on man have shown that the enzyme may be formed in the heart, liver, kidney, and fatty tissues (Korn, 1955; Robinson and French, 1960; Boberg, Carlson, and Normell, 1964; Condon, Tobias, and Datta, 1965; Datta, 1966).

A number of diseases where LPL activities have been reported to be low include cystic fibrosis of pancreas, coeliac disease (Slack et al., 1962; Jakovcic and Hsia, 1963) and biliary cirrhosis (Datta, 1963; Fabian et al., 1967).

This study has shown that LPL activity after heparin in the severe stages of marasmus was lower than that in normal controls. Studies carried out in cases of cystic fibrosis of pancreas would favour the explanation that the decrease of LPL after heparin in patients with this disease is the result of a lack of stimulation of the enzymes due to malabsorption of triglycerides. This conclusion was supported by the observation that a fall in plasma LPL activity was seen after two weeks on a low-fat isocaloric diet and a rise to the initial levels after two weeks of the reintroduction of fat to the diet.
In these marasmic cases, low LPL activity after heparin may not be due to fat malabsorption because comparison of LPL activities after heparin in the initial severe stage of marasmus and those observed 6 weeks later revealed no significant difference (except in two cases with values of 3.425 and 4.090), in spite of the fact that the children showed no signs of intolerance to fat in the diet and that a clinical improvement was evidenced by a gain in weight ( $33.5 \mathrm{~g}$. daily). LPL activities after heparin determined in 4 cases 14 weeks after starting treatment showed little difference from values found in the severe stage. Therefore it may be accepted that the low LPL activity after heparin in marasmus continues for a long time and is not dependent on fat malabsorption.

The low LPL activity reported in cases of biliary cirrhosis of the liver is believed to be due to inability of damaged liver cells to carry out the release of LPL (Datta, 1966; Bosadjiewa et al., 1967; Röding and Liese, 1967). The low LPL activity after heparin in cirrhotic subjects may be due to several causes. SGOT shows a significant negative relation with LPL levels after heparin, from which it may be determined that decreased production appears to be involved.

GOT, GPT, and ICD activities in serum are increased in approximately $50 \%$ of cases of kwashiorkor. The excess enzymes are derived principally from skeletal muscle but also from the liver as a result of cell damage or increased cell fermeability (Edozien, 1961; Waterlow, 1963). Some investigators found no increases in GOT and GPT in children with either marasmus or kwashiorkor (Smith, 1962).

For this reason the low LPL activity cannot be attributed solely to liver damage. A kinetic study of LPL activity may constitute a helpful criterion in evaluating the significance of enzyme levels (Boberg and Carlson, 1964; Geday, 1966). Disappearance rates from plasma and half-life 
calculation revealed no significant differences in this group of cases from values obtained in normal controls.

It, therefore, appears that the low level of LPL activities after heparin in marasmus cannot be explained entirely by the above hypotheses. It is quite possible that the defective synthesis of LPL in cases of marasmus has a common aetiology with other enzyme defects reported in proteincalorie malnutrition. It can also be stated that this functional defect is not corrected in the early stages of recovery.

\section{Summary}

The effect of heparin on LPL activity, the kinetics in the plasma of this enzyme, and the FFA levels in 14 cases of marasmus were investigated in the severe and recovery stages of the disease.

The free fatty acid levels were found to be comparable to normal control values. This finding was in agreement with the absence of fatty liver enlargement in this type of protein-calorie malnutrition.

LPL activity in the plasma after the administration of heparin did not rise as high as observed in the normal controls. This is probably the expression of a defect in the synthesis of this enzyme similar to defects in other enzyme systems observed in states of malnutrition. The defect in synthesis of the enzyme persisted for up to 14 weeks.

\section{REFERENCES}

Bar-on, H., and Stein, Y. (1968). Effect of glucose and fructose administration on lipid metabolism in the rat. $\mathcal{F}$. Nutr., 94, 95.

Boberg, J., and Carlson, L. A. (1964). Determination of heparininduced lipoprotein lipase activity in human plasma. Clin. Chim. Acta., 10, 420.

- - -, and Normell, L. (1964). Production of lipolytic activity by the isolated, perfused dog liver in response to heparin. Life Sci., 3, 1011.

Bosadjiewa, E., Warbanow, G., Markowski, S., Beltschew, L., and Russinow, E. (1967). Ưber die Lipoproteidlipase-Aktivität, die Serumlipide und den Heparineffekt auf den Blutzuckerspiegel bei atrophischer Leberzirrhose und chronischer Hepatitis. Z. ges. inn. Med., 22, 393.

Burns, T. W., Gehrke, C. W., Anigian, M. J., and Langley, P. E. (1963). Effect of insulin on plasma free fatty acids of normal subjects. F. Lab. clin. med., 62, 646.

Condon, R. E., Tobias, H., and Datta, D. V. (1965). The liver and postheparin plasma lipolytic activity in dog and man. $\mathcal{f}$. clin. Invest., 44, 860 .

Datta, D. V. (1963). Post-heparin plasma 'lipoprotein lipase' levels in cirrhosis of the liver. Proc. Soc. exp. Biol. (N.Y.), 112, 1006.
- (1966). The mechanism of low postheparin plasma lipolytic activity (PHLA) in patients with cirrhosis of the liver. $\mathcal{f}$. Lab. clin. med., 67, 461.

Dole, V. P., and Meinertz, H. (1960). Microdetermination of longchain fatty acids in plasma and tissues. $\mathcal{F}$. biol. Chem., 235, 2595.

Edozien, J. C. (1961). Enzymes in serum in kwashiorkor. Pediatrics, 27, 325.

Fabian, E., Kučerová, L., Stork, A., and Sponarova, J. (1967). Die freien Fettsäuren und die Aktivitäten der Postheparinesterase und der Lipoproteidlipase bei Leberzirrhose. $Z$. ges. inn. Med., 22, 74.

Feigelson, E. B., Pfaff, W. W., Karmen, A., and Steinberg, D. (1961). The role of plasma free fatty acids in development of fatty liver. $\mathcal{F}$. clin. Invest., 40, 2171.

Fletcher, K. (1966). Observations on the origin of liver fat in infantile malnutrition. Amer. F. clin. Nutr., 19, 170.

Geday, E. (1966). Lipolysis in plasma after subcutaneous, intramuscular and intravenous heparin in small doses. Acta med. scand., 179, 5 .

Gürson, C. T., and Etili, L. (1968). Relation between endogenous lipoprotein lipase activity, free fatty acids, and glucose in plasma of women in labour and of their newborns. Arch. Dis. Childh., 43,679 .

Hadden, D. R., and Rutishauser, I. H. E. (1957). Effect of human growth hormone in kwashiorkor and marasmus. Arch. Dis. Childh., 42, 29.

Högstedt, B., and Lindquist, B. (1963). Lipoprotein lipase in plasma of the normal newborn: preliminary report. Acta paediat (Uppsala), 52, 61.

Jakovcic, S., and Hsia, D. Y. (1963). Studies on mechanism for decreased lipoprotein lipase in cystic fibrosis of the pancreas. F. Pediat., 62, 25.

Kern, F., Steinmann, L., and Sanders, B. B. (1961). Measurement of lipoprotein lipase activity in post-heparin plasma: description of technique. $\mathcal{F}$. Lipid Res., 2,51 .

Korn, E. D. (1955). Clearing factor, a heparin-activated lipoprotein lipase. I. Isolation and characterization of the enzyme from normal rat heart. $\mathcal{f}$. biol. Chem., $215,1$.

Lewis, B., Hansen, J. D. L., Wittman, W., Krut, L. H., and Stewart, F. (1964). Plasma free fatty acids in kwashiorkor and the pathogenesis of the fatty liver. Amer. F. clin. Nutr., 15, 161.

MacDonald, I., Hansen, J. D. L., and Bronte-Stewart, B. (1963). Liver, depot and serum lipids during early recovery from kwashiorkor. Clin. Sci., 24, 55.

Marks, V. (1959). An improved glucose-oxidase method for determining blood, C.S.F. and urine glucose levels. Clin. Chim. Acta., 4, 395.

Robinson, D. S., and French, J. E. (1960). Heparin, the clearing factor lipase and fat transport. Pharmacol. Rev., 12, 241.

Röding, H., and Liese, W. (1967). Zur Bestimmung der Lipoproteidlipase an artifiziellem Substrat. Z. med. Labortechn., 8, 50.

Slack, J., Nair, S., Traisman, H., Becker, G., Mahler, S., and Hsia, D. Y. (1962). Lipoprotein lipase in cystic fibrosis of the pancreas. F. Lab. clin. med., 59, 302.

Smith, C. E. (1962). Serum transaminases in kwashiorkor. F. Pediat., 61, 617.

Waterlow, J. C. (1963). Metabolic disturbances in proteincalorie malnutrition. In Mild-moderate Forms of ProteinCalorie Malnutrition. Ed. by G. Blix, p. 47. Almqvist and Wiksell, Uppsala.

Correspondence to Professor C. T. Gürson, Department of Pediatrics, Cerrahpaşa Hastanesi, Aksaray, Istanbul, Turkey. 